\title{
PERSEPSI MAHASISWA TERHADAP PELAKSANAAN PEMBELAJARAN DARING PADA JURUSAN PGSD
}

\author{
Winara, Demmu Karo-Karo \\ Surel : Winara@unimed.ac.id
}

\begin{abstract}
Online learning requires evaluation both in terms of the delivery of the media teaching staff used and the maximum learning response from adult students. Learning that is not face to face certainly requires special attention to achieve effective learning goals. Disturbances during online are also a problem of internet network disruption, the online application learning media used by this educator who became a researcher to conduct questionnaire research on PGSD students consisting of 426 students consisting of 4 batches namely 2017, 2018, 2019 and 2020 to make respondents in research. Researchers conducted a questionnaire via google form, there were 8 questions related to online learning questions covering activities during online learning. Student responses to online learning carried out by lecturers are good overall $90 \%$ of student responses to online learning are very good, but $10 \%$ of student responses have not felt satisfaction or are lacking in online learning
\end{abstract}

Keywords: Student Perception, Online Learning, Internet Network

\begin{abstract}
ABSTRAK
Pembelajaran daring membutuhkan evaluasi baik secara penyampian tenaga pengajar media yang digunakan serta respons pembelajran dari peserta didik apkah sudah maksimal. Pembelajran yang tidak bertatap muka tentu memerlukan perhatian khusus untuk mencapai tujuan pembelajran yang efektif. Gangguan selama daring juga jadi permasalahan gangguan jaringan internet, media pembelajaran aplikasi daring yang digunakan oleh pendidik ini yang menjad acuah peneliti untuk melakukan penelitian angket terhadap mahasiswa PGSD terdiri dari 426 mahasiswa yang terdiri dari 4 angkatan yaitu 2017, 2018, 2019 dan 2020 untuk menjadikan responden dalam penelitian. Peneliti melakukan angket melalui google form ada 8 pertanyaan yang berkaitan dengan pembelajran daring pertanyaan meliputi kegiatan selama pembelajran daring. Respons mahasiswa terhadap pembelajran daring yang dilakukan oleh dosen berjlan baik keseluruhan $90 \%$ respons mahasiswa terhadap pelaksanan pembelajran daring sangat baik namun ada $10 \%$ respons mahasiswa belum merasakan kepuasan atau kurang dalam pembelajaran daring.
\end{abstract}

Kata Kunci : Persepsi Mahasiswa, Pembelajaran Daring, Jaringan Internet 


\section{PENDAHULUAN}

Pembelajaran

daring merupakan pemanfaatan jaringan internet dalam proses pembelajaran diharapkan peserta didik leluasa waktu belajar, dapat belajar kapanpun dan dimanapun, Pembelajaran ini merupakan inovasi pendidikan untuk menjawab tantangan akan ketersediaan sumber belajar yang variatif (Isman, 2017). Kondisi ini memberi dampak secara langsung pada dunia pendidikan. Lembaga pendidikan formal, informal dan nonformal menutup pembelajaran tatap muka dan beralih dengan pembelajaran daring (online).

Peralihan pembelajaran, dari yang semula tatap muka menjadi pembelajaran daring memunculkan banyak hambatan bagi guru dan siswa, mengingat hal ini terjadi secara mendadak tanpa adanya persiapan sebelumnya Pembelajaran secara daring merupakan cara baru dalam proses belajar mengajar yang memanfaatkan perangkat elektronik khususnya internet dalam

penyampaian belajar. Pembelajaran daring, sepenuhnya bergantung pada akses jaringan internet. Menurut Imania (2019) pembelajaran daring merupakan bentuk penyampaian pembelajaran konvensional yang dituangkan pada format digital melalui internet. Pembelajaran daring, dianggap menjadi satu-satunya media penyampai materi antara guru dan siswa, dalam masa darurat pandemi. Sebagai seorang pendidik harus mengetahui dan dapat membuat sebuah pembaharuan dalam dunia pendidikan agar dapat mengembangkan proses pembelajaran yang kondusif sehingga dapat diperoleh hasil yang maksimal (Winara \& Haniyyah). Kurang cepatnya umpan balik yang dibutuhkan dalam proses belajar mengajar perlu waktu lebih lama untuk mempersiapkan diri terkadang membuat beberapa orang merasa tidak nyaman karena adanya kemungkinan muncul perilaku frustasi, kecemasan dan kebingungan (Pangondian R. A., Santosa, \& Nugroho, 2019). Dosen sebagai seorang pendidik dan sebagai orang yang memberi ilmu pengetahuan kepada anak didik harus betul-betul memahami kebijakankebijakan pendidikan.

Dengan pemahaman itu Dosen memiliki landasan-landasan berpijak dalam melaksanakan tugas dibidang Pendidikan (Winara, 2020). Massa pandemic covid -19 tentunya pembelajaran dilakukan secara daring proses belajar mengajar banyak menggunakan berbagai media $e$ learning, tentunya hal ini sudah berlangsung 1 tahun proses belajar mengajar itu dilakukan tentunya dalam pembelajaran daring yang di lakukan di PGSD Universitas Negeri Medan para Dosen dan mahasiswa mengalami kendala berupa jaringan, media E-learning selama di gunakan selama proses belajar mengajar hal ini menjadi acuan peneliti untuk melihat proses belajar daring selama pandemic covid-19. Sebagai evaluasi Pendidikan perlunya melakukan penelitian ini secara keseluruhan untuk menindak 
lanjuti kekurangan pembelajaran daring selama pandemik.

\section{METODE PENELITIAN}

Penelitian ini di laksanakan pada mahasiswa PGSD Universitas Negeri Medan dengan jumlah responden 426 mahsiswa terdidi dari semester I dan Semester VI yang aktif melakukan perkulihan daring, penelitian ini di lakukan menggunakan metode kualitatif menggunakan angket terbuka melalui google form dengan 9 pertanyaan mendasar yang sering di alami selama pembelajaran daring tentunya 9 pertanyaan ini sudah melalui validasi ahli materi. Pertanyaan seputar pembelajaran daring yang sering di rasakan mahasiswa selama covid, Adapun pertanyaan yang mewakili aktivitas pembelajaran daring yaitu: 1. Berikan nilai Dalam pembelajaran daring, dosen telah menyiapkan aktivitas (attandance, chat, forum, BBB, Jitsi,quis, dll) 2. menyiapkan aktivitas (attandance, chat, forum, BBB, Jitsi,quis, dll) dan sumber (file, link url,dll) yang sudah dapat diakses pada saat jam perkuliahan.? 3. Berikan nilai kualitas aktifitas dan sumber yang disiapkan dosen telah merepresentasikan tujuan pembelajaran dan telah memuaskan mahasiswa. 4. Berikan nilai jika dosen telah menggunakan aktifitas interaktif yang ada disistem $e$ learning, seperti chat, forum, Big blue button, dan jitsi dengan baik. 5 . Berikan nilai jika dosen telah menggunakan aktifitas interaktif yang ada disistem e-learning, seperti chat, forum, Big blue button, dan jitsi dengan baik. 6. Berikan nilai apabila mahasiswa sering mengalami kegagalan presensi melalui attendance. 7. Berikan nilai apabila tugas yang diberikan dosen terlalu banyak dan terlalu berat. 8 . Pilih salah satu atau beberapa gangguan sistem $e$ learning yang sering terjadi. 9. Pilih salah satu atau beberapa media lain selain e-lerning yang sering digunakan dosen. Penelitian ini untuk mengetahui peroses dan kendala selama pembelajaran daring berlangsung khusus nya di Universitas Negeri Medan di PGSD.

\section{HASIL PENELITIAN DAN PEMBAHASAN}

- Pertanyaan No. 1: Berikan nilai Dalam pembelajaran daring, dosen telah menyiapkan aktivitas (attandance, chat, forum, BBB, dan sumber (file, link url,dll) yang sudah dapat diakses pada saat jam perkuliahan?

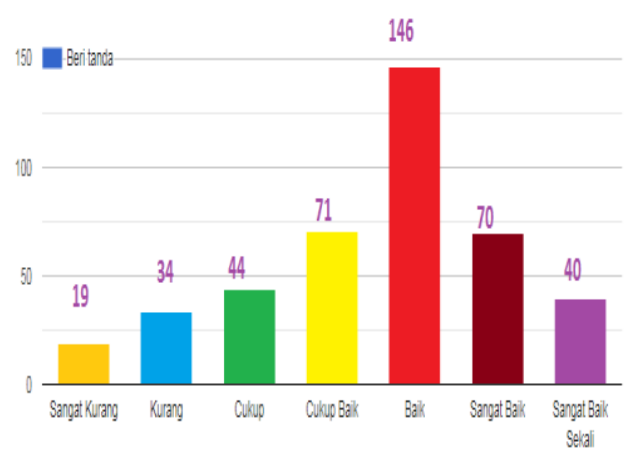

\section{Diagram 1. Responden Memberikan Tanggapan Untuk Pertanyaan No 1.}

Dari data yang didapat pembelajaran daring, dosen telah menyiapkan aktifitas (attandance, chat, forum, BBB, Jitsi,quis, dll) dan 
sumber (file, link url,dll) yang sudah dapat diakses pada saat jam perkuliahan respon mahasiswa yang menyatakan sangat baik sekali, sangat baik, baik,cukup baik, cukup, kurang dan sangat kurang dari 426 Responden.

Tabel 1. Responden Memberikan Tanggapan Untuk Pertanyaan No 1.

\begin{tabular}{l|l|l}
\hline Katagori & responden & $\%$ \\
\hline $\begin{array}{l}\text { Sangat Baik } \\
\text { Sekali }\end{array}$ & 40 & $8.6 \%$ \\
\hline Sangat Baik & 70 & 15.1 \\
\hline Baik & 146 & $31.1 \%$ \\
\hline Cukup baik & 71 & $15,3 \%$ \\
\hline Cukup & 44 & $9.5 \%$ \\
\hline Kurang & 34 & $7.3 \%$ \\
\hline $\begin{array}{l}\text { Sangat } \\
\text { Kurang }\end{array}$ & 19 & $4.1 \%$ \\
\hline
\end{tabular}

Pertanyaan No.1 menunjukan mahasiswa memiliki respon positif sebanyak 40 responden mengatakan sangat baik sekali, 70 responden memberikan tanggapan sangat baik , 146 responden memberi tanggapan baik 71 cukup baik, dan 44 responden memberikan tanggapan cukup. Hanya 19 responden memberikan tanggapan 34 sangat kurang 19 responden sangat kurang sekali.

- Pertanyaan No. 2: Berikan nilai kualitas aktifitas dan sumber yang disiapkan dosen telah merepresentasikan tujuan pembelajaran dan telah memuaskan mahasiswa.

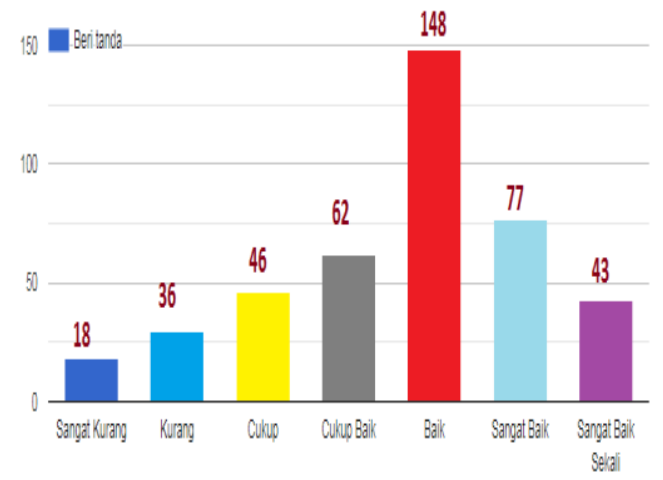

Diagram 2. Responden Memberikan Tanggapan Untuk Pertanyaan No 2.

Data yang di dapat respon mahasiswa tentang kualitas aktifitas dan sumber yang disiapkan dosen telah merepresentasikan tujuan pembelajaran dan telah memuaskan mahasiswa, yang menyatakan sangat baik sekali, sangat baik, baik,cukup baik, cukup, kurang dan sangat kurang dari 426 Responden sebanyak:

Tabel 2. Responden Memberikan Tanggapan Untuk Pertanyaan No 2

\begin{tabular}{l|l|l}
\hline Katagori & responden & $\%$ \\
\hline $\begin{array}{l}\text { Sangat Baik } \\
\text { Sekali }\end{array}$ & 43 & $9.3 \%$ \\
\hline Sangat Baik & 77 & 16.6 \\
\hline Baik & 148 & $32.0 \%$ \\
\hline Cukup baik & 61 & $13,2 \%$ \\
\hline Cukup & 46 & $9.9 \%$ \\
\hline Kurang & 36 & $7.7 \%$ \\
\hline $\begin{array}{l}\text { Sangat } \\
\text { Kurang }\end{array}$ & 18 & $3.8 \%$ \\
\hline
\end{tabular}

Pertanyaan No. 2 menunjukan mahasiswa memiliki respon positif sebanyak 43 responden mengatakan sangat baik sekali, 77 responden memberikan tanggapan sangat baik , 148 responden memberi tanggapan 
baik ,61 cukup baik, dan 46 responden memberikan tanggapan cukup. Hanya 46 responden memberikan tanggapan 36 sangat kurang 18 responden sangat kurang sekali.

- Pertanyaan No. 3: Berikan nilai jika dosen telah menggunakan aktifitas interaktif yang ada disistem e-learning, seperti chat, forum, Big blue button, dan jitsi dengan baik.

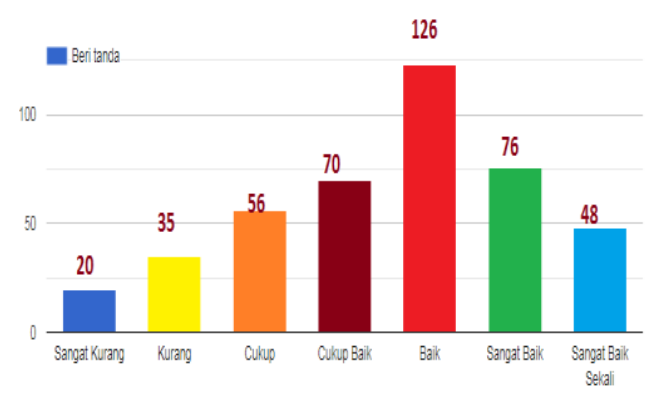

Diagram 3. Responden Memberikan Tanggapan Untuk Pertanyaan No 3

Data yang di dapat respon mahasiswa tentang dosen telah menggunakan aktifitas interaktif yang ada Big blue button, dan jitsi dengan baik. Mahasiswa yang menyatakan sangat baik sekali, sangat baik, baik,cukup baik, cukup, kurang dan sangat kurang dari 426 Responden sebanyak :
Tabel 3. Responden Memberikan Tanggapan Untuk Pertanyaan No 3

\begin{tabular}{l|l|l}
\hline Katagori & responden & $\%$ \\
\hline $\begin{array}{l}\text { Sangat Baik } \\
\text { Sekali }\end{array}$ & 44 & $10.3 \%$ \\
\hline Sangat Baik & 76 & $17.8 \%$ \\
\hline Baik & 126 & $29.5 \%$ \\
\hline Cukup baik & 70 & $16.4 \%$ \\
\hline Cukup & 56 & $13.1 \%$ \\
\hline Kurang & 35 & $8.2 \%$ \\
\hline $\begin{array}{l}\text { Sangat } \\
\text { Kurang }\end{array}$ & 20 & $4.6 \%$ \\
\hline
\end{tabular}

Pertanyaan No.3 menunjukan mahasiswa memiliki respon positif sebanyak 44 responden mengatakan sangat baik sekali, 76 responden memberikan tanggapan sangat baik, 126 responden memberi tanggapan baik, 70 cukup baik, dan 56 responden memberikan tanggapan cukup. Hanya responden memberikan tanggapan 35 sangat kurang 20 responden sangat kurang sekali.

- Pertanyaan No. 4: Berikan nilai jika dosen telah menggunakan aktifitas interaktif yang ada disistem e-learning, seperti chat, forum, Big blue button, dan jitsi dengan baik.

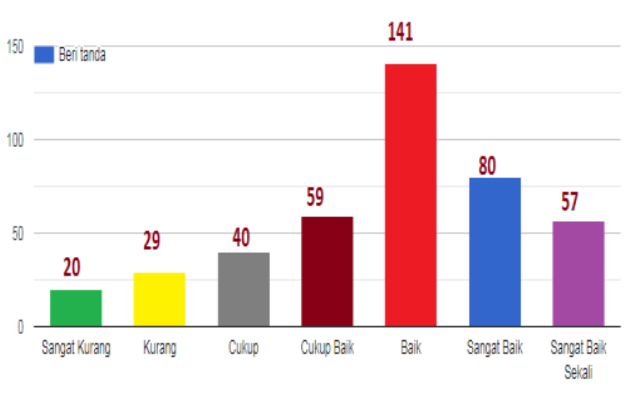

Diagram 4. Responden Memberikan Tanggapan Untuk Pertanyaan No 4. 
Berikan nilai jika dosen telah menggunakan aktifitas interaktif yang ada disistem e-learning, seperti chat, forum, Big blue button, dan jitsi dengan baik Mahasiswa yang menyatakan sangat baik sekali, sangat baik, baik,cukup baik, cukup, kurang dan sangat kurang dari 426 Responden sebanyak :

Tabel 4. Responden Memberikan Tanggapan Untuk Pertanyaan No 4

\begin{tabular}{l|l|l}
\hline Katagori & responden & $\%$ \\
\hline $\begin{array}{l}\text { Sangat Baik } \\
\text { Sekali }\end{array}$ & 57 & $13.3 \%$ \\
\hline Sangat Baik & 80 & $18.7 \%$ \\
\hline Baik & 141 & $33 \%$ \\
\hline Cukup baik & 59 & $13.8 \%$ \\
\hline Cukup & 40 & $9.3 \%$ \\
\hline Kurang & 29 & $6.8 \%$ \\
\hline $\begin{array}{l}\text { Sangat } \\
\text { Kurang }\end{array}$ & 20 & $4.6 \%$ \\
\hline
\end{tabular}

Pertanyaan No.4 menunjukan mahasiswa memiliki respon positif sebanyak 57 responden mengatakan sangat baik sekali, 80 responden memberikan tanggapan sangat baik , 141 responden memberi tanggapan baik ,59 cukup baik, dan 40 responden memberikan tanggapan cukup. Hanya responden memberikan tanggapan 29 sangat kurang 20 responden sangat kurang sekali.

- Pertanyaan No. 5: Berikan nilai apabila mahasiswa sering mengalami kegagalan presensi melalui attendance

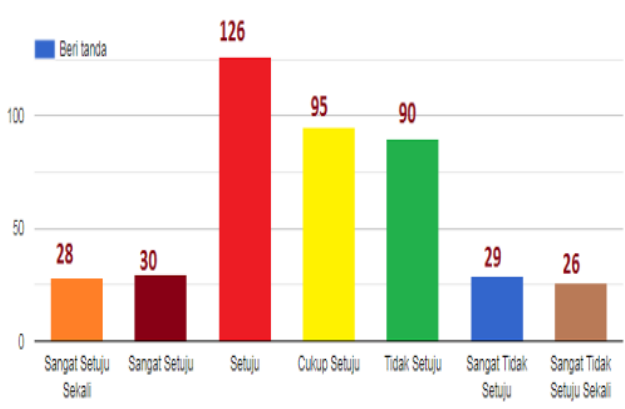

Diagram 5. Responden Memberikan Tanggapan Untuk Pertanyaan No 5.

Berikan nilai jika mahasiswa sering mengalami kegagalan presensi melalui attendance Mahasiswa yang menyatakan Sangat Tidak Setuju Sekali, Sangat Tidak Setuju, Sangat Tidak Setuju, Tidak Setuju Cukup Setuju, Setuju, Cukup Setuju dan Sangat Setuju Sekali dari 426 Responden sebanyak :

Tabel 5. Responden

\section{Memberikan Tanggapan Untuk} Pertanyaan No 5

\begin{tabular}{l|l|l}
\hline Katagori & responden & $\%$ \\
\hline $\begin{array}{l}\text { Sangat Tidak } \\
\text { Setuju Sekali }\end{array}$ & 26 & $6.1 \%$ \\
\hline $\begin{array}{l}\text { Sangat Tidak } \\
\text { Setuju }\end{array}$ & 29 & $6.8 \%$ \\
\hline Tidak Setuju & 90 & $21.1 \%$ \\
\hline Cukup Setuju & 95 & $22.3 \%$ \\
\hline Setuju Setuju & 126 & $29.5 \%$ \\
\hline Sangat Setuju & 26 & $7.0 \%$ \\
\hline $\begin{array}{l}\text { Sangat Sekali S } \\
\text { Seka }\end{array}$ \\
\hline
\end{tabular}

Pertanyaan No.5 menunjukan mahasiswa memiliki respon positif sebanyak 26 responden mengatakan sangat Tidak Setuju sekali, 29 responden memberikan tanggapan sangat Tidak Setuju , 90 responden memberi tanggapan tidak setuju ,95 sangat Setuju, dan 126 responden memberikan tanggapan Setuju. Hanya 
responden memberikan tanggapan 30 cukup setuju 26 responden sangat setuju sekali.

- Pertanyaan No. 6: Berikan nilai apabila tugas yang diberikan dosen terlalu banyak dan terlalu berat.

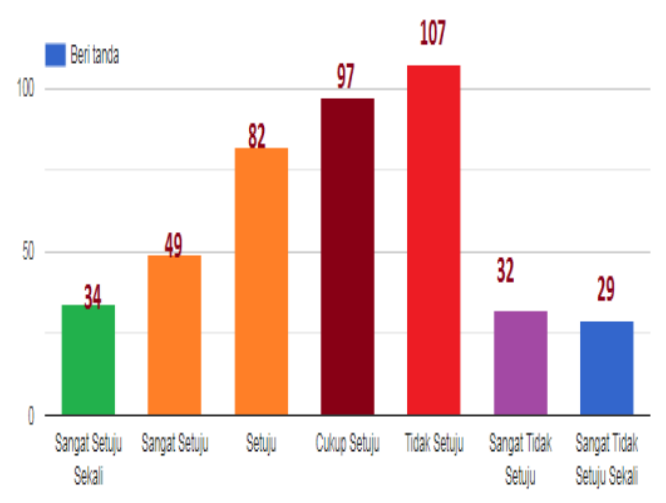

Diagram 6. Responden Memberikan Tanggapan Untuk Pertanyaan No 6.

Berikan nilai apabila tugas yang diberikan dosen terlalu banyak dan terlalu berat. Mahasiswa yang menyatakan Sangat Tidak Setuju Sekali, Sangat Tidak Setuju, Sangat Tidak Setuju, Tidak Setuju Cukup Setuju, Setuju, Cukup Setuju dan Sangat Setuju Sekali dari 426 Responden sebanyak :

Tabel 6. Responden Memberikan Tanggapan Untuk Pertanyaan No 6

\begin{tabular}{l|l|l}
\hline Katagori & responden & $\%$ \\
\hline $\begin{array}{l}\text { Sangat Tidak } \\
\text { Setuju Sekali }\end{array}$ & 29 & $6.8 \%$ \\
\hline $\begin{array}{l}\text { Sangat Tidak } \\
\text { Setuju }\end{array}$ & 32 & $7.5 \%$ \\
\hline Tidak Setuju & 107 & $25.1 \%$ \\
\hline Cukup Setuju & 97 & $22.7 \%$ \\
\hline Setuju Setuju & 82 & $19.2 \%$ \\
\hline Sangat Setuju & 34 & $11.5 \%$ \\
\hline $\begin{array}{l}\text { Sangat Sekali } \\
\text { Sekali }\end{array}$ & $7.9 \%$ \\
\hline
\end{tabular}

Pertanyaan No.6 menunjukan mahasiswa memiliki respon positif sebanyak 29 responden mengatakan sangat Tidak Setuju sekali, 32 responden memberikan tanggapan sangat Tidak Setuju, 107 responden memberi tanggapan tidak setuju, 97 sangat Setuju, dan 82 responden memberikan tanggapan Setuju. Hanya responden memberikan tanggapan 49 cukup setuju 34 responden sangat setuju sekali.

- Pertanyaan No. 7: Pilih salah satu atau beberapa gangguan sistem $e$ learning yang sering terjadi.

\section{Diagram 7. Responden Memberikan Tanggapan Untuk Pertanyaan No 7.}

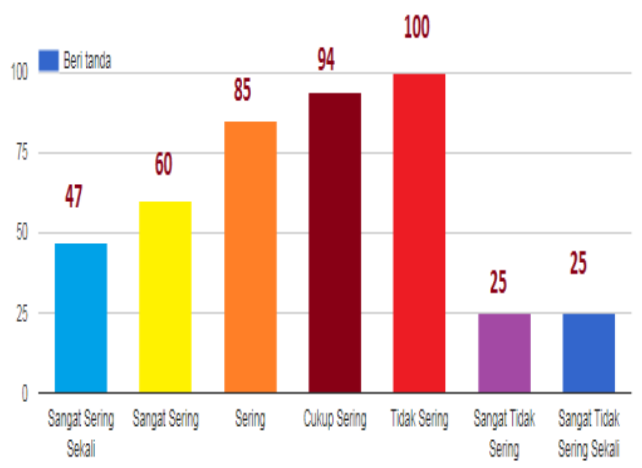

Pertanyaan No.7 menunjukan mahasiswa memiliki respon positif sebanyak 25 responden mengatakan sangat Tidak Sering sekali, 25 responden memberikan tanggapan sangat Tidak Sering, 100 responden memberi tanggapan tidak sering, 94 cukup sering, dan 85 responden memberikan tanggapan Sering. Hanya responden memberikan tanggapan 60 sangat sering 47 responden sangat sering sekali. 
Tabel 7. Responden Memberikan Tanggapan Untuk Pertanyaan No 7

\begin{tabular}{l|l|l}
\hline Katagori & responden & $\%$ \\
\hline $\begin{array}{l}\text { Sangat Tidak } \\
\text { Sering Sekali }\end{array}$ & 25 & $5.8 \%$ \\
\hline $\begin{array}{l}\text { Sangat Tidak } \\
\text { Sering }\end{array}$ & 25 & $5.8 \%$ \\
\hline Tidak Sering & 100 & $23.4 \%$ \\
\hline Cukup Sering & 94 & $22 . \%$ \\
\hline Sering Sering & 85 & $19.9 \%$ \\
\hline Sangat Sering & 60 & $14 \%$ \\
\hline $\begin{array}{l}\text { Sangat Sering } \\
\text { Sekali }\end{array}$ & 47 & $11 \%$ \\
\hline
\end{tabular}

- Pertanyaan No. 8: Pilih salah satu atau beberapa media lain selain elerning yang sering digunakan dosen

Tabel 8. Responden Memberikan Tanggapan Untuk Pertanyaan No 8

\begin{tabular}{l|l|l}
\hline Katagori & responden & $\%$ \\
\hline Instagram & 23 & $6.8 \%$ \\
\hline Facebook & 19 & $4.4 \%$ \\
\hline Telegeram & 20 & $4.6 \%$ \\
\hline Email & 67 & $15.6 \%$ \\
\hline Zoom & 110 & $56.8 \%$ \\
\hline Google Meet & 291 & $68.3 \%$ \\
\hline Wa & 167 & $39.2 \%$ \\
\hline
\end{tabular}

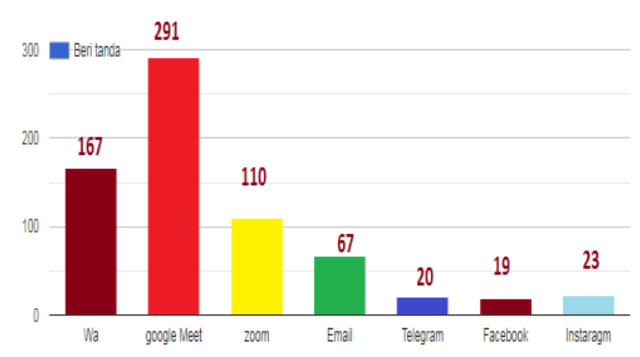

Diagram 8. Responden Memberikan Tanggapan Untuk Pertanyaan No 8.

Pertanyaan no 8 menyangkut pilihan media e-learning yang sering di gunakan mahasiswa selama daring berupa tanggapan pemakai Wattsap
167 responden, pengguna google meet 291 responden, pengguna zoom 110 responden, pengguna email 67 responden, pengguna telegram 20 responden, pengguna facebook 19 responden dan 23 responden pengguna Instagram.

\section{Pembahasan}

Pembelajaran daring di Universitas Negeri Medan khususnya jurusan Pendidikan guru sekolah dasar (PGSD) berjalan sangat baik. Dari 426 responden terdidi dari Angkatan mahasiswa dari 2017, 2018, 2019 dan 2020 memberikan tanggapan yang baik dalam proses pembelajaran daring di jurusan PGSD. Hal ini di buktikan dengan beberapa data yang tertuang di atas ada 8 pertanyaan mendasar proses belajar selama daring 426 responden menanggapi dengan positif pembelajran daring selama 1 semester berjalan baik yang dilakukan Dosen PGSD Universitas Negeri Medan.

\section{SIMPULAN}

Di lihat dari hasil angket mahasiswa sedikit mengalmi kesulitan hanya 9\% mahasiswa belum menjalankan pembelajaran daring dengan efektif tapi $91 \%$ mahasiswa melaksanakan pembelajaran daring dengan baik. Ini menjadi ukuran agar Segenap Dosen selalu memperbarui media atau tugas dalam bentuk daring lebih kreatif sehingga mahasiswa mengikuti pembelajaran dengan maksimal. 


\section{DAFTAR RUJUKAN}

Dewi, Wahyu Aji Fatma. "Dampak

Covid-19 Terhadap

Implementasi Pembelajaran

Daring Di Sekolah

Dasar." Edukatif: Jurnal Ilmu Pendidikan 2.1 (2020): 55-61.

Haniyyah, Winara Ummu. "Pengaruh Penggunaan Media

Pembelajaran Komik Terhadap

Aktivitas Belajar Siswa Sekolah Dasar." Seminar Nasional Pgsd Unimed. Vol. 2. No. 1.

Pangondian, Roman Andrianto, Paulus Insap Santosa, And Eko Nugroho. "Faktor-Faktor Yang Mempengaruhi Kesuksesan Pembelajaran Daring Dalam Revolusi Industri 4.0." Seminar Nasional Teknologi Komputer \& Sains (Sainteks). Vol. 1. No. 1. 2019.

Winara, Winara. "Pengaruh Media Film Berjudul Invictus Untuk Meningkatkan Motivasi Belajar Pada Mata Kuliah Dasar-Dasar Olahraga Pada Mahasiswa Pgsd Unimed Tahun 2020 Pada Saat Daring." Jgk (Jurnal Guru Kita) 5.1: 123-128. 